\title{
Tantangan Praktek Pembelajaran Anak Usia Dini di Masa Pandemi Covid-19
}

\author{
Putu Rahayu Ujianti1 ${ }^{*}$, Nengah Suastika², Putu Sri Darma Dewi ${ }^{3}$ \\ 1,2 Universitas Pendidikan Ganesha, Singaraja, Indonesia \\ ${ }^{3}$ TK Girikarnika Montessori Preschool, Singaraja, Indonesia
}

\section{ART I CLE I N F O}

\section{Article history:}

Received October 27, 2021

Revised October 28, 2021

Accepted November 22, 2021

Available online December 25, 2021

Kata Kunci:

Tantangan Pembelajaran Anak Usia Dini, Pembelajaran Daring

\section{Keywords:}

Early Childhood Education

Challenges, Online Learning

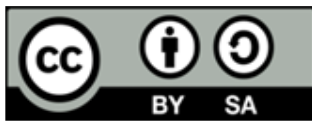

This is an open access article under the

CC BY-SA license.

Copyright (C) 2021 by Author. Published by Universitas Pendidikan Ganesha.

\begin{abstract}
A B S T R A K
Pandemi covid-19 berdampak pada perubahan paradigma pembelajaran. Perubahan tersebut menyebabkan terjadinya berbagai kendala Tujuan penelitian ini adalah untuk mendapatkan gambaran tentang tantangan praktek pembelajaran di PAUD selama pandemi covid-19. Penelitian ini dianalisis menggunakan metode mixed-method dengan desain explanatory sequential yang melibatkan guru dari berbagai daerah di Indonesia. Pengumpulan data dilakukan dengan penyebaran survey dan teknik wawancara. Berdasarkan hasil penelitian, menunjukkan bahwa tantangan yang dihadapi guru dan orang tua dalam praktek pembelajaran di masa pandemi ini rata-rata mengalami hal yang sama. Pertama sistem pembelajaran yang beralih ke sistem online masih belum bisa dilaksanakan secara optimal karena hambatan dalam sumber daya manusia baik dari guru, orang tua, maupun anak terhadap teknologi. Kegiatan evaluasi pembelajaran, pada masa pandemi ini evaluasi yang peserta didik dilakukan penyesuaian namun masih banyak kendala yang dihadapi, didapatkan hasil bahwa ketercapaian tujuan pembelajaran dibeberapa lembaga tidak tercapai secara maksimal. Keterlibatan orang tua yang dalam mendampingi anak anak masih terbatas karena sibuk bekerja, pengetahuan dalam mengajar anak, hingga keterbatasan sarana teknologi. Dalam upaya menghadapi tantangan tersebut, hendaknya pihak sekolah perlu mempertimbangkan kesiapan anak dan orang tua dalam penyampaian materi. Guru sebaiknya mampu menjelaskan ke orang tua bagaimana cara mengajar dan menyampaikan terlebih dahulu materi belajar yang akan diberikan ke anak karena tidak semua orang tua memiliki kemampuan mengajar. Diharapkan dengan begitu, orang tua paham dan dapat membantu proses pembelajaran daring.
\end{abstract}

\begin{abstract}
A B S T RACT
The COVID-19 pandemic has had an impact on changing the learning paradigm. These changes cause various obstacles. This study aims to get an overview of the challenges of learning practice in PAUD during the covid-19 pandemic. This study was analyzed using a mixed-method method with an explanatory sequential design involving teachers from various regions in Indonesia. Data was collected by distributing surveys and interview techniques. Based on the results of the study, it shows that the challenges faced by teachers and parents in learning practices during this pandemic are on average experiencing the same thing. First, the learning system that switches to an online system still cannot be implemented optimally because of obstacles in human resources from teachers, parents, and children to technology. Learning evaluation activities, during this pandemic evaluation were carried out by students, but there were still many obstacles faced, the results showed that the achievement of learning objectives in several institutions was not maximally achieved. The involvement of parents in assisting children is still limited due to busy work, knowledge in teaching children, and limited technological facilities. To face these challenges, schools should consider the readiness of children and parents in delivering material. Teachers should be able to explain to parents how to teach and convey the learning materials that will be given to children in advance because not all parents have the ability to teach. It is hoped that this way, parents will understand and be able to help the online learning process.
\end{abstract}




\section{PENDAHULUAN}

Merebaknya virus Covid-19 telah mengubah banyak hal dalam kehidupan, termasuk dalam hal pendidikan (Putri et al., 2020; Yuzulia, 2021; Zaharah et al., 2020). Jika sebelumnya pembelajaran berpusat di sekolah- sekolah, melalui Surat Edaran Mendikbud No. 4 tentang Pelaksanaan Kebijakan Pendidikan dalam Masa Darurat Penyebaran Corona Virus Disease (Covid-19) maka sejak terhitung mulai 24 Maret 2020, sebagian besar kegiatan tatap muka guru dan siswa di sekolah dikurangi, dan ditiadakan (Fikri et al., 2021; Iswatiningsih et al., 2020). Konsekuensi dari penutupan sekolah secara fisik dan mengganti dengan belajar di/dari rumah sebagaimana kebijakan pemerintah adalah adanya perubahan sistem belajar mengajar (Anugrahana, 2020; Malyana, 2020). Pengelola sekolah, siswa, orang tua, dan guru harus bermigrasi ke sistem pembelajaran digital atau online, yang lebih dikenal dengan istilah e-learning atau dikenal dengan istilah pembelajaran dalam jaringan atau "pembelajaran daring" di Indonesia (Aderholt, 2020; Pratiwi, 2020). Pembelajaran daring memiliki karakteristik yaitu a) penyajian materi ajar dalam berbagai bentuk, antara lain teks, grafik, atau elemen multi media lainnya, b) komunikasi antara pengajar dan siswa dilakukan secara serentak maupun tidak, dengan memanfaatkan fitur seperti video conference, chat rooms, atau forum diskusi online, c) pembelajaran sifatnya virtual/maya, d) materi ajar mudah untuk diperbarui, e) komunikasi dan interaksi bisa formal ataupun informal tergantung pada media atau fitur yang digunakan, f) pemanfaatan internet secara luas (Srihartini \& Pratami, 2020; Trisnadewi \& Muliani, 2020). Pembelajaran jarak jauh dengan sistem daring ini berlaku mulai jenjang taman kanak-kanak hingga SMU dan perguruan tinggi. Mau tidak mau para guru, siswa, orang tua, dan pihak terkait lainnya melakukan penyesuaian-penyesuaian agar ruang-ruang kelas tatap muka di sekolah bisa beralih ke ruang virtual. Berbagai tantangan dihadapi oleh para guru maupun siswa karena banyak yang belum terbiasa menggunakan berbagai moda belajar daring. Meskipun ada pemberlakuan kurikulum darurat, namun pertanyaan utamanya adalah tetap soal kemampuan para guru mentransfer pengetahuan seefektif ketika pembelajaran dilakukan secara tatap muka, dan kemampuan siswa dalam mengembangkan berbagai pengetahuan dan ketrampilan sebagaimana yang tertuang dalam capaian pembelajaran meski tanp hadir secara fisik di sekolah (Sadikin, 2020; Yuzulia, 2021).

Keterbatasan infrastruktur yang berimbas pada kuat lemahnya sinyal internet di suatu daerah, ketersediaan alat komunikasi berupa gawai dan komputer, serta kemampuan membeli pulsa/kuota internet adalah sebagian dari tantangan nyata implementasi daring di lapangan (Arizona et al., 2020; Ulfa \& Mikdar, 2020). Tugas guru tidak hanya menyampaikan informasi kepada peserta didik, tetapi harus menjadi fasilitator yang bertugas memberikan kemudahan belajar (facilitate of learning) kepada seluruh peserta didik, agar mereka dapat belajar dalam suasana yang menyenangkan, gembira, penuh semangat, tidak cemas, dan berani mengemukakan pendapat secara terbuka (Mulyasa., 2013). Dengan demikian maka yang dimaksud sebagai fasilitator adalah guru harus mempersiapkan diri dalam keadaan apapun termasuk dalam keadaan pandemi saat ini. Berbagai keterbatasan dan tantangan di lapangan adalah hal yang harus dapat dikelola guru agar pembelajaran tetap dapat berlangsung. Hasil penelitian mandiri menunjukkan, khusus untuk jenjang pendidikan anak usia dini. Pendidikan Anak Usia Dini (PAUD) adalah suatu upaya pembinaan yang ditujukan kepada anak sejak lahir hingga berusia enam tahun (versi WHO hingga delapan tahun) yang dilakukan melalui pemberian rangsangan pendidikan untuk membantu pertumbuhan dan perkembangan jasmani dan rohani, fisik, mental spiritual anak, sehingga anak memiliki kesiapan untuk memasuki pendidikan lebih lanjut (Fardana, 2016).

Tantangan yang dihadapi dalam pembelajaran jarak jauh atau belajar dari rumah ini sedikit berbeda. Pertama, tujuan pendidikan untuk anak-anak yang masuk di rentang usia dini, yaitu bayi baru lahir hingga usia enam hingga tujuh tahun, adalah untuk menstimulasi segenap aspek perkembangan mereka (fisik motorik, kognitif, bahasa, sosial, emosi, dan agama). Biasanya mulai usia tiga tahun anak-anak sudah masuk ke kelompok bermain, lalu usia empat tahun bersekolah di taman kanak-kanak hingga berusia enam hingga tujuh tahun. Beberapa anak berusia di bawah tiga tahun dititipkan oleh orang tuanya yang bekerja di Tempat Penitipan Anak dan diwajibkan mengakses layanan tumbuh kembang anak baik di posyandu atau puskesmas terdekat, khususnya terkait imunisasi dan penimbangan berat badan. Khusus untuk di jenjang taman kanak-kanak, tujuan anak bersekolah adalah selain menstimulasi berbagai aspek perkembangannya juga untuk memberikan kesempatan bersosialisasi dan menyiapkan anak masuk ke sekolah dasar yang pembelajarannya memang lebih terstruktur dengan waktu yang lebih panjang. Perbedaan yang kedua, model pembelajaran untuk anak usia dini tidak sama dengan anak-anak di jenjang yang lebih tinggi (SD dan seterusnya). Anak usia dini belajar melalui bermain, lebih banyak bergerak dan aktif karena tugas perkembangan mereka memang mensyaratkan demikian. Anak usia dini juga belajar melalui pembiasaan dengan melihat dari contoh dan model orang dewasa di sekitarnya. Hal ini berimplikasi pada perbedaan yang ketiga, yaitu pendekatan pedagogis untuk jenjang pendidikan anak usia dini berbeda dengan di jenjang SD dan seterusnya. Jika tidak diperhatikan secara khusus, akan menjadi tantangan yang tidak mudah bagi proses pembelajaran anak. Peran orang tua menjadi sangat penting karena mengambil porsi yang besar 
dalam praktek pembelajaran jarak jauh (Lilawati, 2020).Tujuan penelitian ini adalah untuk mendapatkan gambaran tentang tantangan praktek pembelajaran di PAUD selama pandemi covid-19.

\section{METODE}

Penelitian menggunakan mixed-methode atau metode kombinasi/campuran, dengan desain explanatory sequential, di mana komponen kuantitatif dikumpulkan terlebih dahulu kemudian dianalisa, lalu hasilnya digunakan untuk menyusun komponen kualitatif, yang fungsinya untuk mendapatkan hasil yang integratif serta lebih mendalamn (Mustaqim, 2016; Sugiyono, 2014). Oleh karena itu, dalam metode penelitian kombinasi (mixed- method), data dikumpulkan secara kuantitatif dan kualitatif, karena kedua jenis data tersebut dibutuhkan dalam penelitian ini, lalu kemudian masing-masing dianalisis sesuai jenis data secara berurutan atau sequential.
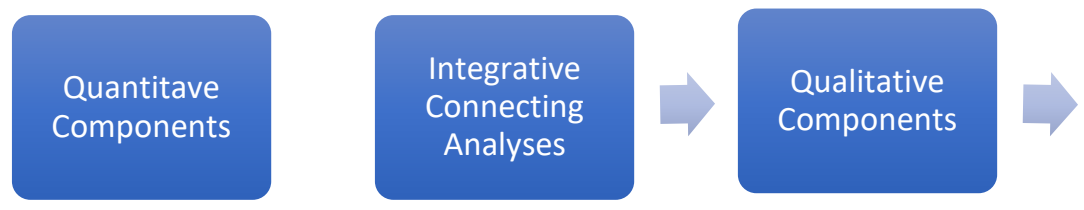

Integrative

Interpretations

for Insights--

Dive Deeper

Gambar 1. Tahapan penelitian

Penelitian ini dilakukan di lembaga PAUD yang tersebar di Provinsi Bali, Jawa Timur, NTB dan NTT. Subyek penelitian adalah para guru dan pendidik anak usia dini yang tersebar di keempat Provinsi tersebut dan orang tua dari anak-anak yang bersekolah di lembaga PAUD tersebut. Kriteria responden untuk kuesioner adalah guru di lembaga PAUD, baik di TK ataupun di kelompok bermain yang tersebar di keempat Provinsi. Area Jawa dan Bali dianggap mewakili daerah yang jaringan internetnya cukup lancer, sementara daerah NTB dan NTT adalah daerah dengan jaringan internet tidak selalu stabil dan lancar. Pemilihan subyek wawancara berdasarkan kesukarelaan, artinya hanya mereka yang bersedia yang akan diwawancara, dengan kriteria yaitu guru di lembaga PAUD yang selama pandemi tetap melaksanakan pembelajaran secara kontinyu. Diharapkan unsur keterwakilan terpenuhi, yaitu minimal satu orang subyek mewakili setiap Provinsi. Penjaringan subyek yaitu para guru dan orang tua dari anak-anak yang bersekolah di lembaga PAUD di empat Provinsi. Data kuantitatif diperoleh dengan melakukan survei berupa penyebaran kuesioner kepada para guru dan orang tua. Selanjutnya data kuantitatif diolah dan hasilnya digunakan sebagai bahan untuk menyusun pertanyaan wawancara mendalam (in depth interview) kepada para guru yang sebelumnya telah dimintai kesediaan untuk diwawancarai. Data kualitatif dianalisis dan diintegrasikan dengan data kuantitatif. Data kuantitatif dari kuesioner dianalisa dengan teknik statistik deskriptif. Sementara data kualitatif dari hasil wawancara eknik analisis yang digunakan adalah teknik analisis tematik, dengan menggunakan analisis tematik, peneliti menemukan 'pola' yang pihak lain tidak melihatnya jelas. Setelah menemukan pola, maka akan mengklarifikasi atau mengkode pola tersebut dengan memberi label, definisi atau deskripsi. Untuk menjaga kesahihan data kualitatif, diupayakan dengan cara 1) panduan wawancara dibuat terstruktur mengacu pada hasil kuesioner, 2)dilengkapi dengan foto dan dokumen pendukung

\section{HASIL DAN PEMBAHASAN}

Hasil

Selama ini pembelajaran di PAUD dilakukan secara offline atau tatap muka yang mengarah pada stimulasi aspek-aspek perkembangan anak. Anak akan secara langsung mendapatkan pengalaman terhadap hal-hal baru yang dipelajarinya. Selain itu, tidak hanya segi akademik saja, tetapi juga non akademik yaitu pembentukan karakter sejak usia dini. Namun, selama pandemi berlangsung proses pembelajaran pada satuan pendidikan beralih ke sistem online atau dalam jaringan. Hal ini memberikan pengaruh besar terhadap proses pembelajaran. Peneliti telah melakukan survei kepada 157 guru di seluruh Indonesia yang dilakukan sebanyak dua tahap, yaitu tahap satu sebanyak 80 guru dan tahap dua sebanyak 77. Berdasarkan survei tahap satu, data menunjukkan bahwa praktek pembelajaran paling banyak dilaksanakan selama pandemi ini adalah campuran daring dan tatap muka dengan persentase jawaban $58,8 \%$. Untuk persentase pembelajaran daring adalah $30 \%$ dan tatap muka sebesar $11,2 \%$. Hasil survei tahap satu disajikan pada Gambar 2. Hasil survei tahap dua menunjukkan bahwa praktek pembelajaran selama pandemi ini dilaksanakan dalam 3 cara yaitu daring/online, luring/tatap muka, dan campuran (daring dan tatap muka). Persentase tertinggi adalah praktek pembelajaran campuran yaitu 55,8\%, diikuti 
praktek pembelajaran daring dengan persentase 41,6\%, dan persentase terendah yaitu tatap muka sebesar 2,6\%. Adapun hasil survei tahap 2 disajikan pada Gambar 3.

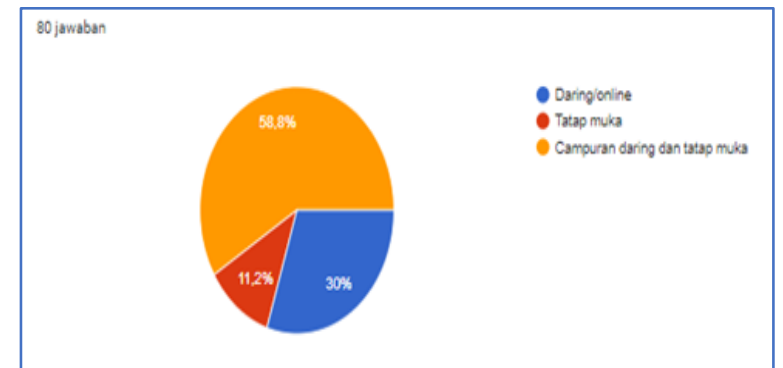

Gambar 2. Diagram Hasil Survei Praktek Pembelajaran Selama Pandemi Tahap Satu

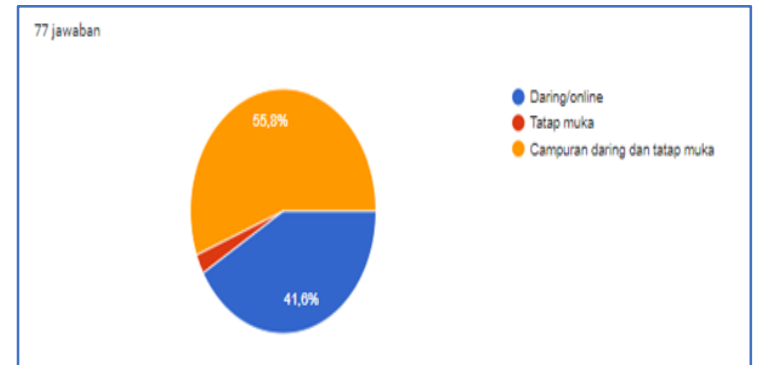

Gambar 3. Diagram Hasil Survei Praktek Pembelajaran Selama Pandemi Tahap Dua

Hal lain yang menjadi fokus peneliti dalam penelitian ini adalah intensitas anak masuk ke sekolah untuk mengikuti kegiatan pembelajaran selama pandemi ini. Fakta di lapangan menunjukkan bahwa intensitas siswa yang masuk sekolah lebih dari satu kali seminggu berada pada persentase terbanyak yaitu $55 \%$, kemudian intensitas siswa masuk sekolah sekali seminggu memiliki persentase 26,3\%, dan tidak pernah ke sekolah (hanya berupa pemberian tugas) sebesar 18,8\%. Data tersebut dapat ditunjukkan pada Gambar 4. Selain rancangan kegiatan, penilaian dan evaluasi anak juga disesuaikan dengan keadaan anak dan sekolah masing-masing. Bagaimanapun juga evaluasi sangat penting untuk dilakukan untuk mengukur ketercapaian pembelajaran dan perkembangan anak. Penilaian yang ada di PAUD menggunakan pencatatan observasi, dokumentasi, anekdot, dan hasil karya. Dari hasil survei yang telah dilakukan sebanyak 97,3\% guru melakukan evaluasi perkembangan anak di masa pandemi, sementara sisanya menjawab bahwa mereka tidak melakukan evaluasi perkembangan anak. Angka 97,3\% merupakan jumlah yang cukup besar. Namun guru masih mengeluhkan terkait sulitnya proses evaluasi karena tidak bisa secara optimal dan akurat melihat perkembangan anak, terutama yang menerapkan sistem pembelajaran daring. Selama ini, guru memaklumi apabila anak dibantu oleh oraang tua dalam menyelesaikan tugas karena memang mereka masih butuh bimbingan, guru akan tetap menilai dan memberikan reward hasil belajar tersebut. Persentase jawaban responden dapat dilihat pada Gambar 5.

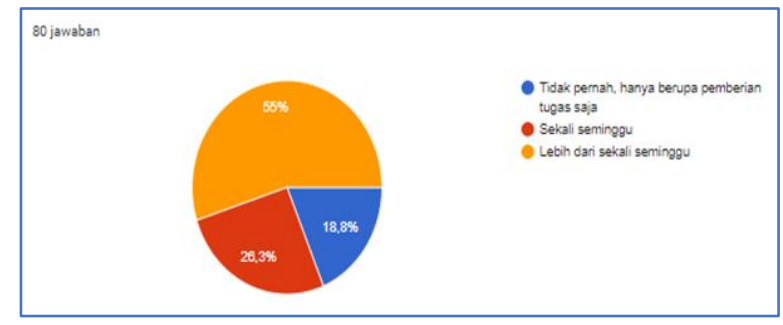

Gambar 4. Diagram Hasil Survei Siswa Masuk ke Sekolah Selama Pandemi

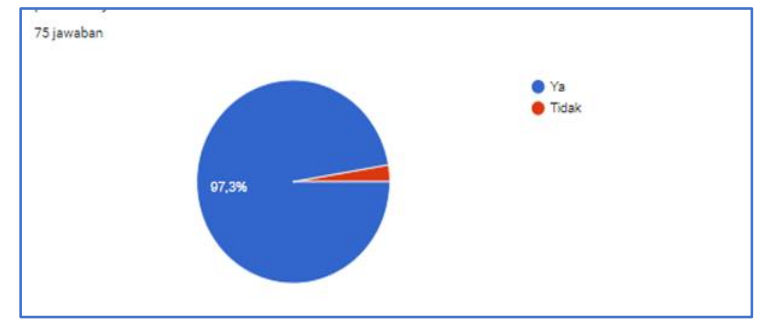

Gambar 5. Diagram Hasil Survei Pelaksanaan Evaluasi Perkembangan Anak

Kebijakan pembelajaran jarak jauh dari pemerintah berimplikasi bagi anak usia dini dalam hal emosi, pengasuhah anak, kesehatan, serta pembelajaran. Untuk saat ini peran orang tua sangat penting untuk mendampingi anak di rumah. Guru di sekolah mengupayakan agar anak tetap belajar selama pandemi dengan membuat lembar kerja siswa, mengadakan kelas online, dan lain-lain. Tentu saja untuk anak usia dini yang rentang usianya masih terbilang kecil memerlukan pendampingan saat belajar dari rumah. Dari data yang peneliti kumpulkan sebagian besar sekolah melibatkan orang tua dalam proses pembelajarannya. Pada survei tahap satu dari 80 responden 79 responden mengatakan bahwa mereka melibatkan orang tua dalam proses pembelajaran. Kemudian untuk tahap dua seluruh responden yang berjumlah 77 melibatkan orang tua dalam proses pembelajaran anak seperti pada Gambar 6. Gambar 7 menunjukkan angka yang sangat bagus, karena para responden mengatakan bahwa peran orang tua paling penting sebagai pendamping dalam sistem pembelajaran saat ini. Dimulai dari pengambilan tugas, pengerjaan tugas, penerimaan informasi dari guru, hingga mendampingi siswa saat belajar di rumah. Peran lainnya adalah sebagai fasilitator seperti menyediakan media belajar (gawai). Dukungan orang tua dapat menentukan keberlangsungan pendidikan anak. Maka orang tua dituntut untuk dapat menggunakan teknologi dan kreatif dalam mendampingi anak saat belajar. 


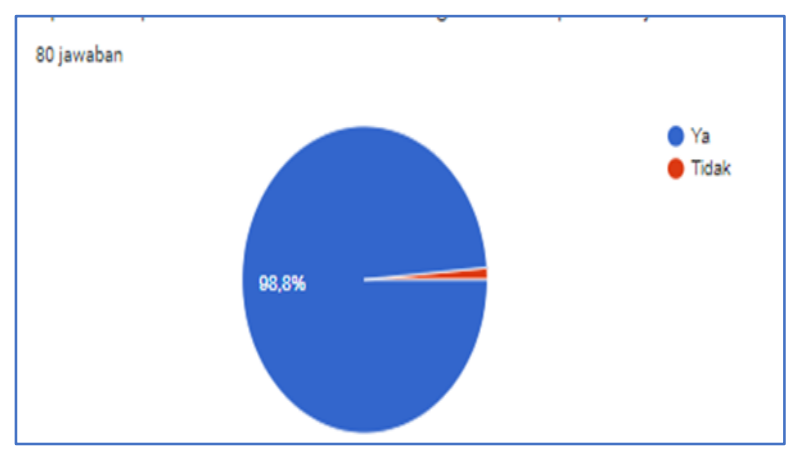

Gambar 6. Diagram Hasil Survei Keterlibatan Orang Tua Dalam Pembelajaran Tahap Satu

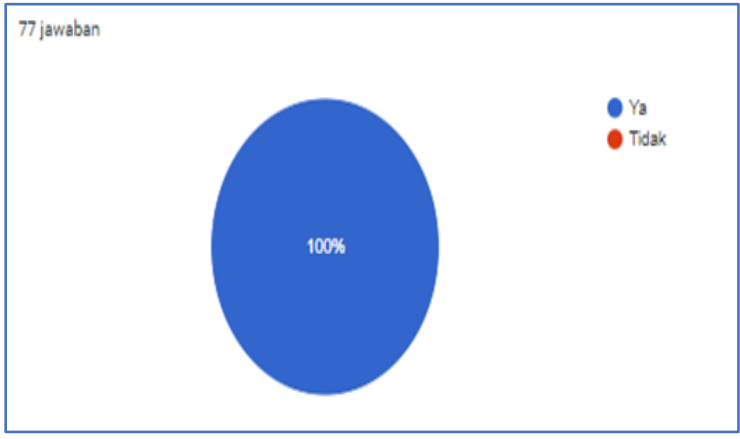

Gambar 7. Diagram Hasil Survei Keterlibatan Orang Tua Dalam Pembelajaran Tahap Satu

\section{Pembahasan}

Pembelajaran selama pandemi Covid-19 ini mengakibatkan perubahan yang signifikan, seluruh jenjang pendidikan termasuk pendidikan anak usia dini (PAUD) secara tiba-tiba bertransformasi dan beradaptasi untuk melakukan pembelajaran dari rumah melalui media daring. Adanya perubahan ini tentu saja menjadi tantangan besar bagi guru-guru karena belum terbiasa menggunakan teknologi untuk menyelenggarakan pembelajaran. Dilihat dari kesiapan guru PAUD menghadapi pembelajaran daring, masih ada guru yang mengatakan belum siap melakukan pembelajaran daring. Sehubungan dengan hal tersebut, tentu saja menjadi hambatan yang besar karena guru merupakan komponen penting dalam proses pembelajaran. Tidak hanya guru, banyak hambatan lain yang menjadi tantangan yaitu kesiapan peserta didik, rancangan kegiatan dan evaluasi pembelajaran, serta keterlibatan orang tua di rumah dalam mendampingi anak. Gambar 4 menunjukkan bahwa masih terdapat sekolah yang belum sepenuhnya bisa melaksanakan pembelajaran daring yang dicanangkan oleh pemerintah dan banyak sekolah yang melaksanakan pembelajaran secara tatap muka di sekolah sebanyak lebih dari satu kali seminggu. Hal ini disebabkan oleh banyak faktor sehingga guru-guru memutuskan untuk mengizinkan anak-anak belajar dengan sistem tatap muka di tengah masa pandemi. Selain melakukan survei berupa angket, peneliti juga melakukan wawancara kepada beberapa responden. Hasil menunjukkan bahwa faktor yang menjadi pertimbangan para guru mengizinkan anak belajar kembali di sekolah dalam situasi pandemi, yaitu: 1) kurangnya sarana prasarana yang dimiliki anak-anak di rumah untuk mengikuti kegiatan daring seperti alat komunikasi dan jaringan internet, 2) orang tua anak yang kurang paham teknologi sehingga tidak dapat menggunakan aplikasi-aplikasi pembelajaran daring, sedangkan anak membutuhkan pendampingan orang tua saat belajar di rumah, 3) kesiapan guru dalam melaksanakan pembelajaran secara daring, 4) dan ada persetujuan orang tua dan ijin dari dinas untuk melakukan kegiatan pembelajaran tatap muka di sekolah.

Dari hasil survei dan wawancara dapat disimpulkan bahwa terdapat beberapa faktor yang menjadi tantangan dalam proses pembelajaran daring yaitu, kurangnya sarana prasarana, kemampuan guru, dan minimnya pengetahuan orang tua mengenai penggunaan teknologi. Sejalan dengan hal tersebut, tantangan pembelajaran daring yang dihadapi dunia pendidikan di Indonesia adalah kualitas guru dan prasarana (Purwanto et al., 2020; Surahman et al., 2020). Selain itu, banyak tantangan yang dihadapi pendidik, peserta didik, maupun orang tua terkait pelaksanaan sistem pembelajaran jarak jauh antara lain kemampuan menggunakan media online dan keterbatasan jaringan internet (Basar, 2021; Fikri et al., 2021). Berdasarkan paparan tersebut terlihat jelas bahwa penerapan sistem pembelajarang daring masih belum bisa dilaksanakan secara optimal karena beberapa hambatan khususnya pada sumber daya manusia baik dari guru, orang tua, maupun siswa terhadap teknologi.Pemerintah telah merancang kurikulum darurat covid-19 yang lebih sederhana dari kurikulum sebelumnya dan menyesuaikan dengan kondisi saat ini. Kurikulum darurat tersebut diterbitkan oleh Menteri Pendidikan dan Kebudayaan Republik Indonesia Nomor 719/P/2020 tentang Pedoman Pelaksanaan Kurikulum pada Satuan Pendidikan dalam Kondisi Khusus. Kurikulum yang digunakan dapat menyesuaikan dengan kondisi peserta didik. Namun, di lapangan masih banyak sekolah yang belum menerapkan kurikulum darurat covid-19. Ditunjukkan dengan data hasil survei para guru di berbagai daerah yang tetap menggunakan panduan yayasan dan kegiatan pembelajarannya lebih dipersingkat.

Pada masa covid-19 ini penilaian yang paling sering digunakan berdasarkan data hasil survei dan wawancara adalah hasil karya dan dokumentasi. Penilaian hasil karya merupakan teknik penilaian dengan melihat prosedur yang dihasilkan oleh anak setelah melakukan suatu kegiatan. Penilaian dokumentasi merupakan catatan peristiwa yang dilakukan oleh anak. Dokumen bisa berbentuk seperti foto, tulisan, rekaman maupun video (Aji, 2020; Munawaroh, 2017). Guru meminta bantuan orang tua untuk mengirimkan hasil belajar anak melalui video atau foto, selanjutnya guru akan mengobservasi hasil 
dokumentasi tersebut. Sebenarnya cara penilaian tersebut masih menjadi problematika dan tidak dapat dijadikan tolak ukur capaian pembelajan secara mutlak karena guru tidak dapat memantau proses belajar anak saat di rumah seperti pada saat di sekolah. Ketercapaian tujuan pembelajaran selama pembelajaran daring sebagian besar responden mengakatan kurang atau tidak tercapai secara maksimal. Para guru harus banyak melakukan penyesuaian dari sebelumnya, hal tersebut mengakibatkan tujuan pembelajaran dari setiap tema tidak semua dapat tercapai. Selain itu, karena terbatasnya waktu interaksi guru dan anak menyebabkan kurang optimalnya penilaian anak, karena guru tidak sepenuhnya mengetahui sejauhmana perkembangan anak.

Berdasarkan data yang diperoleh melalui survei dan wawancara kendala yang paling sering dihadapi saat pembelajaran daring yaitu kurangnya waktu orang tua dalam mendampingi anak karena sibuk bekerja. Kendala lainnya adalah kurangnya pemahaman orang tua terhadap pembelajaran untuk AUD dan bagaimana cara mengajarkannya, serta kurangnya respon orang tua terhadap informasi yang diberikan sekolah. Penyebab dari timbulnya kendala-kendala tersebut adalah tidak semua orang tua memiliki pengetahuan mengenai perkembangan anak dan keterampilan mengajar, hal ini tentunya membuat orang tua kesulitan dalam mendampingi anak di rumah saat belajar. Apalagi orang tua memiliki presepsi bahwa mengajar adalah tugas guru di sekolah, namun pada posisi ini orang tua menggantikan sosok guru di sekolah. Selain itu, tidak semua orang tua melek teknologi dan paham cara penggunaan teknologi. Kendala bagi orang tua dalam mendampingi anak selama pembelajaran daring yaitu kesulitan dalam mengoperasikan gawai (Rigianti, 2020; Utami, 2020). Terlebih kondisi orang tua yang tidak memungkinkan untuk selalu mengawasi anakya dalam belajar. Penelitian sebelumnya juga mengungkapkan mengenai kendala-kendala yang dihadapi oleh orang tua dalam pembelajaran daring, yaitu tidak adanya hanphone, jaringan internet, kesibukan orang tua sehingga tidak bisa mengawasi anak secara penuh, dan orang tua tidak memahami materi pembelajaran sehingga kesulitan menjelaskan kepada anak (Purwanto et al., 2020; Utami, 2020; Wardani \& Ayriza, 2020). Sebagai pendamping utama dalam pembelajaran pada masa pandemi ini, maka orang tua memiliki beberapa poin penting. Orang tua menjadi subjek penting yang mengamati hambatan dan proses pembelajaran anak. Maka dari itu, orang tua akan mengetahui dengan sangat jelas apa yang dibutuhkan anaknya. Orang tua dapat dilibatkan bersama guru untuk mengkonsultasikan kondisi anak sebagai acuan dalam membuat materi atau penugasan belajar. Melihat hal ini pula, penting bagi guru untuk membuatkan rencana pembelajaran yang dibahasakan ke orang tua bukan ke anak saja, karena orang tua harus tahu apa yang harus mereka lakukan di rumah sebagai guru alternatif sehingga memudahkan mereka dalam mendampingi anak belajar di rumah.

\section{SIMPULAN}

Hasil penelitian menunjukkan bahwa seluruh komponen pembelajaran mengalami hambatan selama pandemi covid-19 ini. Hal ini menyebabkan banyak penyesuaian yang dilakukan oleh lembaga sekolah agar anak-anak tetap mendapat pendidikan. Dalam upaya menghadapi tantangan tersebut, hendaknya pihak sekolah perlu mempertimbangkan kesiapan anak dan orang tua dalam penyampaian materi. Guru sebaiknya mampu menjelaskan ke orang tua bagaimana cara mengajar dan menyampaikan terlebih dahulu materi belajar yang akan diberikan ke anak karena tidak semua orang tua memiliki kemampuan mengajar. Diharapkan dengan begitu, orang tua paham dan dapat membantu proses pembelajaran daring.

\section{DAFTAR RUJUKAN}

Aderholt, R. (2020). Coronavirus Outbreak Shining An Even Brighter Light on Internet Disparities in Rural America. The Hill.

Aji, R. H. S. (2020). Dampak Covid-19 pada Pendidikan di Indonesia: Sekolah, Keterampilan, dan Proses Pembelajaran. SALAM: Jurnal Sosial Dan Budaya Syar-I, 7(5). https://doi.org/10.15408/sjsbs.v7i5.15314.

Anugrahana, A. (2020). Hambatan, Solusi dan Harapan : Pembelajaran Daring Selama Masa Pandemi Covid19 Oleh Guru Sekolah Dasar. Jurnal Pendidikan Dan Kebudayaan, 10(3), 282-289. https://doi.org/10.24246/j.js.2020.v10.i3.p282-289.

Arizona, K., Abidin, Z., \& Rumansyah, R. (2020). Pembelajaran Online Berbasis Proyek Salah Satu Solusi Kegiatan Belajar Mengajar Di Tengah Pandemi Covid-19. Jurnal Ilmiah Profesi Pendidikan, 5(1), 6470. https://doi.org/10.29303/jipp.v5i1.111.

Basar, A. M. (2021). Problematika Pembelajaran Jarak Jauh Pada Masa Pandemi Covid-19. Edunesia : Jurnal Ilmiah Pendidikan, 2(1), 208-218. https://doi.org/10.51276/edu.v2i1.112.

Fardana, N. A. N. (2016). Psikologi Perkembangan dan Pendidikan Anak Usia Dini Sebuah Bunga Rampai. Prenada Media Grup. 
Fikri, M., Ananda, M. Z., Faizah, N., Rahmani, R., Elian, S. A., \& Suryanda, A. (2021). Kendala Dalam Pembelajaran Jarak Jauh di Masa Pandemi Covid-19: Sebuah Kajian Kritis. Jurnal Education and Development Institut Pendidikan Tapanuli Selatan, 9(1), 145-148. http://journal.ipts.ac.id/index.php/ED/article/view/2290.

Iswatiningsih, D., Fauzan, Dluhayati, \& Lestari, Y. K. (2020). Efektivitas Pembelajaran Bahasa Indonesia Daring di Masa Pandemi COVID-19 Dalam Meningkatkan Kemampuan Berbahasa Siswa SMP. Jurnal Pendidikan, Kebahasaan Dan Kesustraan Indonesia, 5, 141-156.

Lilawati, A. (2020). Peran Orang Tua dalam Mendukung Kegiatan Pembelajaran di Rumah pada Masa Pandemi. Jurnal Obsesi: Jurnal Pendidikan Anak Usia Dini, 5(1), 549. https://doi.org/10.31004/obsesi.v5i1.630.

Malyana, A. (2020). Pelaksanaan Pembelajaran Daring dan Luring dengan Metode Bimbingan Berkelanjutan pada Guru Sekolah Dasar di Teluk Betung Utara Bandar Lampung. Jurnal Ilmiah Pendidikan Dasar Indonesia, 2(1), 67-76. https://doi.org/10.52217/pedagogia.v2i1.640.

Mulyasa. (2013). Teacher's Competency Standard And Certification. PT Remaja Rosdakarya.

Munawaroh, H. (2017). Pengembangan Model Pembelajaran dengan Permainan Tradisional Engklek Sebagai Sarana Stimulasi Perkembangan Anak Usia Dini. Jurnal Obsesi : Jurnal Pendidikan Anak Usia Dini, 1(2), 86. https://doi.org/10.31004/obsesi.v1i2.19.

Mustaqim. (2016). Metode Penelitian Gabungan Kuantitatif Kualitatif/Mixed Methods Suatu Pendekatan Alternatif. Jurnal Intelegensia, 04(1), 1-9.

Pratiwi, E. W. (2020). Dampak Covid-19 Terhadap Kegiatan Pembelajaran Online Di Perguruan Tinggi Kristen Di Indonesia. Perspektif Ilmu Pendidikan, 34(1), 1-8. https://doi.org/10.21009/pip.341.1.

Purwanto, A., Pramono, R., Asbari, M., Santoso, P. B., Wijayanti, L. M., Choi, C. H., \& Putri, R. S. (2020). Studi Eksploratif Dampak Pandemi COVID-19 Terhadap Proses Pembelajaran Online di Sekolah Dasar. EduPsyCouns: Journal of Education, Psychology and Counseling, 2(1), 1-12. https://edukatif.org/index.php/edukatif/article/view/142.

Putri, R. S., Purwanto, A., Pramono, R., Asbari, M., Wijayanti, L. M., \& Hyun, C. C. (2020). Impact of the COVID19 pandemic on online home learning: An explorative study of primary schools in Indonesia. International Journal of Advanced Science and Technology, 29(5), 4809-4818. https://search.bvsalud.org/global-literature-on-novel-coronavirus-2019 ncov/resource/en/covidwho-830197.

Rigianti, H. A. (2020). Kendala Pembelajaran Daring Guru Sekolah Dasar Di Kabupaten Banjarnegara. Jurnal Pendidikan Dan Pembelajaran Ke-SD-An, 7(2), 297-302. https://doi.org/10.31316/esjurnal.v7i2.768.

Sadikin, A. (2020). Pembelajaran Daring di Tengah Wabah Covid-19. Jurnal Ilmiah Pendidikan Biologi,6(2). https://doi.org/10.22437/bio.v6i2.9759.

Srihartini, Y., \& Pratami, M. L. (2020). Pembelajaran Pendidikan Anak Usia Dini Online di Era Pandemi Covid-19. TARBIATUNA Journal of Islamic Education 1 / Tarbiatuna, 1(1), 1-21. http://journal.laaroiba.ac.id/index.php/tarbiatuna/article/view/219.

Sugiyono. (2014). Metode Penelitian Pendidikan Pendekatan Kuantitatif, Kualitatif, dan R\&D. Alfabeta.

Surahman, Santaria, \& Setiawan. (2020). Tantangan Pembelajaran Daring Di Indonesia. Journal of Islamic $\begin{array}{lll}\text { Education } \quad \text { Management, } & \text { 89-98. }\end{array}$ http://ejournal.iainpalopo.ac.id/index.php/kelola/article/view/1397.

Trisnadewi, K., \& Muliani, N. M. (2020). Pembelajaran daring di masa pandemi Covid-19. Yayasan Kita Menulis.

Ulfa, Z. D., \& Mikdar, U. Z. (2020). Dampak Pandemi Covid-19 terhadap Perilaku Belajar , Interaksi Sosial dan Kesehatan bagi Mahasiswa FKIP Universitas Palangka Raya. Journal of Sport Science and Education, 5(2), 124-138.https://journal.unesa.ac.id/index.php/jossae/article/view/9654.

Utami, E. (2020). Kendala dan Peran Orangtua dalam Pembelajaran Daring Pada Masa Pandemi Covid-19. Prosiding Seminar Nasional Pascasarjana, 471-479.

Wardani, A., \& Ayriza, Y. (2020). Analisis Kendala Orang Tua dalam Mendampingi Anak Belajar di Rumah Pada Masa Pandemi Covid-19. Jurnal Obsesi: Jurnal Pendidikan Anak Usia Dini, 5(1), 772. https://doi.org/10.31004/obsesi.v5i1.705.

Yuzulia, I. (2021). The Challenges Of Online Learning During Pandemic : Students' V oice. Jurnal Bahasa Dan Sastra, 13(1), 8-12. https://doi.org/10.31294/w.v13i1.9759.

Zaharah, Kirilova, G. I., \& Windarti, A. (2020). Impact of Corona Virus Outbreak Towards Teaching and Learning Activities in Indonesia. Salam: Jurnal Sosial Dan Budaya Syar'i, 7(3), 269-282. http://doi.org/10.15408/sjsbs.v7i3.15104. 